
internationales

vol. $32-n^{\circ} 1 \mid 2016$

Les migrations des Roms roumains en Europe

\title{
From Slum to City Dweller, Trajectories of Integration of the "Roma" Families of an Affirmative Action Program in France
}

Du bidonville à la vie citadine, les trajectoires d'intégration de familles « roms » ayant participé à un projet de discrimination positive en France

Del chabolismo a la vida citadina, las trayectorias de integración de familias «roma» que participaron a un proyecto de acción positiva en Francia

Kàtia Lurbe i Puerto

\section{OpenEdition}

\section{Journals}

Electronic version

URL: https://journals.openedition.org/remi/7659

DOI: 10.4000/remi.7659

ISSN: $1777-5418$

Publisher

Université de Poitiers

Printed version

Date of publication: 1 March 2016

Number of pages: $79-100$

ISBN: 979-10-90426-27-6

ISSN: 0765-0752

\section{Electronic reference}

Kàtia Lurbe i Puerto, "From Slum to City Dweller, Trajectories of Integration of the "Roma" Families of an Affirmative Action Program in France", Revue européenne des migrations internationales [Online], vol. $32-n^{\circ} 1$ | 2016, Online since 01 March 2018, connection on 16 April 2022. URL: http:// journals.openedition.org/remi/7659 ; DOI: https://doi.org/10.4000/remi.7659 


\title{
From Slum to City Dweller, Trajectories of Integration of the "Roma" Families of an Affirmative Action Program in France
}

\author{
Kàtia Lurbe i Puerto' ${ }^{1}$
}

Different $\mathrm{NGOs}^{2}$, the Committee of Experts on Roma and Travellers ${ }^{3}$ and the census of 2013 on illicit settlements commissioned by the Délégation Interministérielle à I'Hébergement et à l'Accès au Logement (DIHAL) estimate that nearly 20.000 "Roma" live in France. The lack of reliable statistics on this population is mainly due to the refusal of French authorities to officially recognize ethnic minorities. To mitigate the absence of data, public authorities and associations have fabricated an estimation based on the record of the migrants coming from Eastern Europe since the fall of the Berlin Wall who live in slums. Their arrival stems from the economic upheavals of Post-communism, and the integration of Bulgaria and Romania within the Schengen Area in 2002 and the European Union (UE) in 2007. However, even in the case of existing official statistics on their presence, numbers would be inaccurate and problematic as the ethnic-based ontology of this classification is contested. As this article develops, the term "Roma" informs us more about how France deals with foreign, urban poverty than it provides an account of the ethnic identity and cultural patterns of life of the individuals labelled as such. Perceived as a threat to the Republican social contract, "Roma" designates a heterogeneous group of people sharing the common experience of a life of impoverishment, social exclusion and disdain.

In France, their extremely precarious lives and conflictive relationships with the Nation-state have started to receive larger media coverage since the so-called "Roma sequence of the summer of 2010" (Canut and Hobé, 2011). The events of that summer marked a shift in the definition of the "Roma issue".

\footnotetext{
1 Sociologist (MA University of Warwick, PhD EHESS-Paris and UAB), Research Fellow, Assistance Publique des Hôpitaux de Paris and Lecturer at Paris Descartes University, Research Unit, Department of Nutrition (Pr Czernichow), Hôpital Ambroise Paré, 9 avenue Charles de Gaule, 92104 Boulogne-Billancourt; katia.lurbe-puerto@aphp.fr

2 Cf. rapports of ROMEUROPE (http://www.romeurope.org) and Médecins du Monde (http://www.medecinsdumonde.org).

3 Cf. http://www.coe.int/t/dg3/romatravellers/mgsrom_en.asp
} 
On one hand, the events reconfigured the difficulties of and the problems provoked by individuals seen as belonging to the "Roma community" into a national public problem. Since then, news relating to "Roma" has from time to time moved from the fait-divers section to the national politics section. Added to this, there is the over-mediatised noise, dirt, violence and crime that presumably typify the "Roma", and there is the anger and hate uttered by some local residents and elected representatives against them which has grown in visibility. As Windels (2014) shows, such discourses are currently politically exploited by mayors who are unable to meet their citizens' expectations in terms of housing, employment, purchasing power and public services and by politicians to conceal important neoliberal measures.

On the other hand, during that summer of 2010, the French government became overtly a major player responsible for the instability and violence that characterises the daily lives of most "Roma". Usually unpublished by the media, the voices expressing exasperation in front of the racist policies and the ruthlessness of public authorities against the "Roma" became more visible. Moreover, France was confronted with widespread international condemnation for having broken the European Convention on Human Rights. The "Roma sequence of 2010" is a revealing of the republican ethnicization of politics (Geisser, 2005).

According to Fassin (2014), mainstream public policies towards the "Roma" rely on biopolitics of rejection based either on an attitude of total neglect or the systematic eviction of the inhabitants of illicit settlements. In some exceptional cases, a few local initiatives for the "insertion of Roma" have been launched, some of which have State support. The first projects date from the end of 1990s (e.g. the Sénart Project). To date, around twenty projects of this kind have been carried out in France; some have been completed while others are still in progress (Olivera, 2013). These projects have been called "projects for the insertion of Roma", "reception sites", "villages of insertion" according to the type of measures undertaken to relocate the families, the existence (or not) of social accompaniment, the number of beneficiaries and the actors involved (municipality, department, region, prefecture, NGO).

Such local projects are exceptional, in particular in the context of the French republican model, which rejects any policies targeted at ethnic minorities (Bessone et al., 2013). These projects have rarely been evaluated in France. When they are concluded, no information is disseminated on their objectives or achievements. Little is known about the experience of the participants. If some records of the institutional player are confined to the archives of the project, the voices of the "Roma" are not. Aware of this gap but also of the need for sound research on a population against whom a widespread prejudice prevails, this article analyses the trajectories of integration of the families of the Senart Project. More specifically, it addresses three questions: What assessment have the participants made of the Project? What ideal types of families' integration can be drawn from this case-study? What are the elements that constitute the specificity of these different (and maybe also differing) ideal types?

We examine next the French politics on "Roma" by doing a critical deconstruction of the "Roma sequence of summer 2010". Then, we describe the fieldwork undertaken and the intersectional approach applied. After a brief presentation of the Project, we analyse the participants' trajectories of integration. 


\section{The Political Fabrication of the "Roma Issue"}

Events date back to the assault on the gendarmerie of Saint-Aignan on the $18^{\text {th }}$ July 2010. That day, around forty French Gens du voyage attacked the gendarmerie in reprisal for the police killing of one of their family members. The government announced, in response, the systematic dismantling of illicit camps, giving priority to those of "Roma". President Nicolas Sarkozy's "Speech of Grenoble" delivered on the $30^{\text {th }}$ July $^{4}$ and the Circular of the $5^{\text {th }}$ August 2010 of the Ministry of the Interior ${ }^{5}$ announced a forthcoming reform of the policy against illegal immigration intended to prevent "Roma" from returning once a year to benefit from French repatriation grants. The concatenation of declarations and policies emanating from the assault represents a case-study to shed light on French politics towards the "Roma".

\section{The Ethnicization of the Margins of Europe}

To begin with, the "Roma sequence of 2010" demonstrates how "Roma" are officially conflated with Gens du voyage. The term Gens du voyage, which is equivalent to "travellers", is an administrative category invented at the beginning of 1970s in France and currently defined by the law of the $5^{\text {th }}$ October 2000 to class individuals whose traditional housing environment constitutes mobile residences, even if most have been sedentary for several generations (Robert, 2007). Most are French nationals. Within it, several distinctions are found that relates to the individuals' ethnic origins (Pirdé, Yéniches, Sinti-Piémontais, Manush) or their membership to craftspeople bodies. They range from families in deprivation to others with comfortable living-conditions. The group "Roma/ Travellers" brings together the imagined-community of experience of those whose "freedom" is understood as a lack of respect for the common norms of living-together.

The variety of the core elements that reifies "Roma" categorisation hinges on a range of different peculiarities, not altogether shared by everyone labelled as such. The "Roma" are however, commonly thought to be socially incongruous: they settle in or hang around improbable places; practise shady activities; dress in a "gypsy style", in pierced and dirty clothes; have dark skin and hair; wear gold teeth and, speak an unknown language (Lurbe i Puerto and Le Marcis, 2012). As Ragaru (2015) shows in the context of Bulgaria, the "Roma" are the archetypal figure of the poor; both social downgrading and marginalisation leading to a symbolic crossing of the ethnic borders. Presumed to be naturally predisposed to a nomadic style of life and reluctant to commit with the social contract underlying the contemporary city dwellers' lifestyle, "Roma" are suspected of lacking the will to integrate into modern society.

For the last thirty years, historical and anthropological research has questioned the appropriateness of applying a primordialist approach to the understanding of the socio-cultural realities of "Roma" populations (Reyniers, 1993;

4 Cf. http://www.lefigaro.fr/politique/le-scan/2014/03/27/25001-20140327ARTFIG00084-lediscours-de-grenoble-de-nicolas-sarkozy.php

5 Cf. http://www.bulletin-officiel.developpement-durable.gouv.fr/fiches/BO201016/ met_20100016_0100_0031.pdf 
Asséo, 1994; Stewart, 2002; Cossée, 2010). Accordingly, a categorical construction has resulted from the convergence of the political interests of a small group of elites from minority communities aiming at manufacturing a European Roma identity, and of the newly arisen experts on "Roma". These experts, who work for or collaborate with international human rights organisations, have endorsed a leading role in the struggle for the recognition of minorities, the promotion of multiculturalism and the integration of deprived groups of people (Olivera, 2011). In 1971 the World Romani Congress put forward the generic term of "Roma" (meaning "married man" in Romani) to push its claim for international recognition to the foreground.

Over time very diverse international authorities - the United Nations, the World Bank (WB), the European Union (EU) and the Council of Europe (CoE) have given "Roma" an institutional existence - even if their works on the matter are dissimilar (Doytcheva, 2015). In 1979 the United Nations assigned them a consultative status as "Roma nation", a State without territory, within its Economic and Social Council. The terminology used by the $\mathrm{CoE}^{6}$ has varied from its first text relating to the "Roma" in 1969 to the adoption in 2010 of the generic term of "Roma" - in line with the Declaration of Strasbourg of 2010 that adopted the strategy of destigmatisation promoted by Roma organizations (Liégeois, 2012). Soundly informed of the heterogeneous situations of the individuals and groups labelled as "Roma", the CoE has highlighted the social exclusion and racial discrimination they face as a common point to legitimise their recognition as a larger "authentic European minority" and the launch of a strategic framework to develop targeted inclusive policies. The EU, which since 2005 has considered them a "transnational minority", has addressed the "Roma issue" through three separate and to some extent differing angles: the protection of minorities, and human rights and anti-discrimination (especially during the post-communism context and the EU enlargement to Central and Eastern countries); the struggle against social exclusion and poverty; and the securityfocused management of migration (Ragaru, 2015).

A cross-categorization of the "Roma" as a transnational minority has gradually emerged at the risk of the over-homogenisation of the plural historical trajectories (Asséo, 2004). As a politically-constructed category, it underlines an ethnicization of poverty and social exclusion as well as revealing the tensions underpinning the way international authorities deal with minorities and their cultural specificities.

\section{Space Policing, Slum Eviction and Community Deportation}

The governmental reaction to the assault on the gendarmerie provoked international controversy. In the "Speech of Grenoble", President Sarkozy announced the deportation of all "Roma" living in slums. The exchanges between the French Presidency and the CoE elucidate how the French government has addressed "the Roma issue" as a national security affair and a spatial problem requiring eviction measures.

6 Cf. Council of Europe Descriptive Glossary of terms relating to Roma issues 2006, updated version of 18 May 2012. 
In reaction to the "Speech of Grenoble", the Vice-President responsible for Justice, Fundamental Rights and Citizenship at the CoE, Vivian Reding, declared that France had breached the Anti-discrimination directive 2004/38/ CE. Subsequently, President Sarkozy justified the measures taken on the basis of the protection of public order and the prevention of illegal immigration coming from Eastern Europe. They were not directed, he contended, at a particular ethnic group but at foreigners having committed criminal acts. Yet in his answer, a whole racialized community was also linked to criminality, and their presence described as a threat against "national security", a legal term normally used for extraordinary situations when the peace and survival of the State is considered to be at stake. His declarations were indeed officially instituting the type of practices of "spatial policing" (Lussault, 2009) that public authorities with the support of neighbourhood communities had commonly implemented to ostracize "Roma" (Windels, 2014): namely, the control of the space by means of police's identity checks and repetitive evictions.

In turn, Reding proclaimed the launch of a formal infringement proceeding against France on the suspicion that its government was executing mass deportations based on ethnic origin. But what could have lead the government of Sarkozy to be taken before the European Court of Justice resulted in a futile gesture. The CoE finally opted for expressing disapproval for human rights abuse reasons. The European Commission put French policy of deportation of unauthorised immigrants under indictment. Nevertheless, none of this has ceased the ongoing evictions and deportation campaigns.

"The Roma Sequence of 2010" displays how public problems relating to socio-economically deprived Eastern-European migrants come within the scope of a differentialist and segregationist historical continuum that is not totally dissociated from the French republican model, which fosters an individualist, universal and difference-blind conception of citizenship (Doytcheva, 2015). Furthermore, republican universalism paradoxically promotes the "visibilisation" of minority specificities (Simon and Zappi, 2005) and the ethnicization of the social question (Geisser, 2005; Lurbe i Puerto, 2015).

\section{Denied Willpower of Social Integration}

The events of 2010 also illustrate how public policies targeting "Roma" are based on the presumption that their "culture" is incompatible with the republican social contract. Even if not all "Roma" live in shantytowns and squats in the metropolitan area of majors cities, the inhabitants of these spaces of misery are the most visible ones (Legros and Vitale, 2011). Caught in a web of victimblaming, they are presumed to be living in such extreme conditions because of their lack of will to adhere to the rules of the labour market, respect private property and comply with the urban norms of living-together. They are alleged not to want to make the necessary efforts as if living in a shantytown and leaving a slum-life were easy things to do. Their supposed culture is ironically taken as the cause of the poverty they face - a poverty which mainly results from the marginalisation enforced by public authorities (Fassin, 2014).

Under the government of President François Hollande (2012 - present), public policies have become more repressive against “Roma" (Legros, 2014; Fassin, 
2014). Their priority rests on the respect of private property and the securitybased management of deprived migrants; not on improving the life conditions of the inhabitants of shantytowns. According to the current circular of the $26^{\text {th }}$ of August 20127, the implementation of any measure of rehousing and social accompaniment has become subjected to the prior court decision of the eviction of the illicit encampment. Moreover, it institutes as another condition, a triage of the beneficiaries via a social diagnosis. As regards to social accompaniment, it normalises the existing practices towards "Roma" migrants and commissions the DIHAL to provide methodological support. No specific budget is allocated; it is simply requested to apply for European funds.

During his mandate as Head of the DIHAL, Prefect Alain Régnier has regularly faced a rejection against "Roma" from the local representatives - who are, according to the circular, a key player for the setting up of social accompaniment measures (Fouteau, 2014). As stated by the Public Defender of Rights (Report of June 2013), evictions have increased under this circular. Most of them are pronounced without giving evidence of the threat for safety and security that the concerned settlements supposedly constitute. The methods applied for the diagnoses are far from what is required for genuine social work. Despite the DIHAL's specifications, the quality and impact of these diagnoses depend in practice on the professionalism of the social workers leading them; they are generally done in haste and strongly subjected to a previously-fixed number of available places and the requirements of the financiers (Maillary, 2013). The heterogeneity of the criteria taken into account reveals notorious territorial inequalities. Finally, the proposals for the temporary relocation of inhabitants are insufficient, inadequate and even opposite to the aim sought. For instance, the over-systematic solution of relocating the families by asking them to call the over-booked 115 emergency number for homeless people tends to separate the family members and usually offer them filthy hostel rooms, far from their daily economic activities and the school of their children.

Furthermore, as current Prime Minister Manuel Valls declared in March 2013 when commenting on the few projects of temporary housing and social accompaniment aimed at "Roma" migrants: "it can only concern a minority [of families] as lamentably the occupants of encampments do not wish to integrate for cultural reasons or because they are caught into begging and prostitution networks". Furthermore, due to suspected misuse of the Humanitarian Return Aid, this repatriation grant was specifically suspended for "Roma" 8 and revised downward for EU migrants in January 2013". This illustrates how a so-called "humanitarian" policy ultimately serves National Security interests and is in practice differences-oriented.

Public policies relating to "Roma" are underscored by a biopolitics of rejection that is administrated at the local level via a technological arsenal intended to dissuade them to stay longer in France. No real political project governs them, just a local-based managerial rationality aiming at "cleaning" out

7 Cf. http://circulaire.legifrance.gouv.fr/pdf/2012/08/cir_35737.pdf

8 Cf. http://www.lemonde.fr/societe/article/2012/12/07/manuel-valls-annonce-la-fin-de-Iaide-au-retour-pour-les-roms_1801840_3224.html\#KC8fyOhE2Xu5ZQPo.99

9 Cf. http://www.service-public.fr/actualites/002636.html 
the territory. As Fassin (2014) argues, the ethnicization of the "social question" (here, urban poverty) is politically (and noisily) exploited in order to uncover the contemporary crisis of governance and loss of sovereignty of the State in front of the expansion of Neoliberalism.

\section{The Case Study}

In the context of France, the Sénart Project ${ }^{10}$ is an exceptional example of affirmative action addressed to a specific ethnically-defined minority. It is one of the rare local public actions that allied accommodation and a social accompaniment program to achieve the re-insertion in terms of employment, housing, schooling, healthcare and tax payment for twenty-eight out of the thirty-four Romanian families (thirty-nine women, thirty-five men and sixty-nine under-18) who participated. This Project took place two years before the integration of Romania within the Schengen Area in 2002 and ended four months after the accession of Romania to the EU in 2007. It originated in the wake of the urban policies against social exclusion launched in the mid-1990s. Indeed, cities are considered in France as the privileged place for the construction of the politics of integration. By targeting specific areas in order to redress background socioeconomic inequalities, urban policies are able to develop transitory, priority actions addressed to particular populations, without questioning the republican principles of universality (Doytcheva, 2007).

Launched in 2000 in a dormitory-town area within the metropolitan area of Paris, the Sénart Project started as a two-year emergency solution for the temporary relocation of around thirty families who, after facing their umpteenth eviction, fortuitously parked their old damaged caravans at the public car park located in the symbolically powerful site between the church and the city hall of Lieusaint $(6,363$ inhabitants in 1999). With a shantytown at the core of the town, local authorities could not carry on turning a blind eye to the situation of these families who had in fact been residents since 1994, on the margins of the Sénartaise urban way of life and well-known to the local organisations supporting undocumented migrants. For local residents, representatives and organisations, the development of precarious housing represents an expansion of deprivation and seems incompatible with the social representation of a "modern city". It also demonstrates the negligence of public authorities, apparently incapable of resolving the problem of poverty and policing their territories (Legros, 2010).

A first partnership agreement was signed between the Prefecture of the Department of Seine-et-Marne, the Urban Management Unit of Sénart and the mayor of Lieusaint to set up a two-year program that would urgently administer temporary accommodation for the families on a wasteland of the outskirts of the residential area. In addition, an eighteen-month family census was completed by two part-time staff members of the Urban Management Unit of Sénart, who also counted on the support of some local activists. This first phase intended to be a simple political gesture to reduce the visibility of slums in the Newtown of Sénart - which was at that time in its full urban development stage. However,

10 Cf. Lurbe i Puerto (2013 and 2015) for a detailed analysis of the implementation of the Project. 
the census ultimately questioned the stigma attached to the inhabitants and put forward, with sounded arguments, the idea of taking the Project further in terms of time and content (Lurbe i Puerto, 2015).

In 2002, the Project got extended for five more years to develop a Romatargeted social accompaniment program, which began right after that the French government had transposed the European antidiscrimination directives into national legislation. It was mainly funded with State resources coming from the Newtown urban development policy which had been implemented in Sénart since 1973, and the French law for the regulation of travellers of the $5^{\text {th }}$ July 2000 , which imposed the construction of sites for travellers on municipalities of more than 5,000 inhabitants.

On the basis of affordability, the signatories of the second Agreement decided to restrict the follow-up integration Project to twenty-eight families. The Prefecture stood resolute in the idea that although it would exclusively concern a group of "Roma", the actions to be implemented had to comply with le droit commun (literally "common law") - i.e., the application of the principle of republican equality which is paradoxically defined as opposite to any measure of affirmative action. The Project staff, in discussion with local organisations, short-listed the eligible families according to their judgement on who would be the most likely to succeed in terms of socio-economic integration (those individuals with no crime records and judged to have a potential ability to adopt the mainstream "normalised lifestyle" of the French dormitory city areas in agreement with immigration law). The privilege/oppression structure prevailing in the eligibility criteria corresponded to an interweaving of categories in which the nuclear families in the best economic and educational positions would be prioritised if they consisted either of a man living in a couple or of a single woman with children; the families with their children in school were at the top of the hierarchy. The Project illustrates how, according to a pragmatic rational, republican axiology comes to accommodate the process of ethnicization. This process underpins urban policies when tackling the excess of colourrelated inequalities that threaten the social and economic equilibrium of society (Doytcheva, 2007).

A social worker, a social educator, a site warden and a part-time secretary were recruited to constitute the socio-educational support team. They were mandated to assist the families with their administrative procedures, develop a series of socio-educational interventions to create favourable conditions for their socio-economic insertion. The fulfilment of these objectives necessitated a partnership with different players working at the local, regional and state level on the regulation of immigrants' administrative situation, labour insertion, education, health and social security affairs. The socio-educational team was deliberately feminized in order to, according to the signatory institutions, respond better to the needs related to early childhood as well as to the will to stimulate the employability of the women. These two major priorities of the Project were based on the theses insisting on the role of women as effective social development agents for their community.

Two years after it ended, I was granted research funding from the Institut National de Prévention et d'Éducation à la Santé and the Institut de Recherche 
en Santé Publique, allowing me to do a retrospective analysis of the implementation of the Project and undertake a four-year ethnographic study on its participants. In the following paragraphs, I briefly describe my fieldwork.

\section{Brief Description of the Fieldwork}

For the first eighteen months, I undertook a series of conversational interviews with each family at their home. I met with thirty-two families of the Project (i.e., the ones currently living in Sénart). This part of the study was aimed at achieving a first panoramic overview of their life narratives. Whilst looking at the interplay between their roots (belonging) and routes (mobility) (Christensen and Jensen, 2012), I asked them for their experience of the Project and how it influenced their identity construction and current life conditions. Interviews were held in a mixture of three languages: French, Romanian and Catalonian.

Most first encounters were done in collaboration with Stephanie Achte, research collaborator, who after ten years living in Bucharest had become a fluent Romanian speaker. Even more valuable, she was able to keep a nonjudgemental contact with the families, which is a key condition for the feasibility of any ethnographical work among socially stigmatized minorities. For subsequent encounters, I managed by using a "patchwork language" consisting of French and the very basic Romanian I was learning while doing the research. In the few occasions of communication deadlock, my mother tongue Catalonian would bridge our distinct linguistic worlds. From the $10^{\text {th }}$ month of fieldwork, I held regular meetings to discuss my research findings with Dana Cernautanu, who has extensive professional experience as a social worker among Romanian migrants. Her collaboration helped me to keep an informed critical gaze intended to put things in perspective and in context.

Alongside this, I started a documentary analysis of the Project archives, annual reports and press coverage, which I completed with thematicallyfocused interviews with the professionals who had been involved (from the health, education and social work sectors) and who were still in contact with the families. Drawing from the panoramic study, I also selected three distinct families according to their different current life conditions, on whom I conducted a two-year monographic work of their life-courses. The first family represented the nuclear family lifestyle and breadwinner model. The second concerned the extended family, with three generations living in the same household, whose main income proceeded from social security disability allowance. The last one was an elderly couple living in a one-room public housing apartment.

I opted to apply an intersectional analysis to understand the complexity of social identity and inequalities as well as the subjectivation of intertwined forms of oppression (Bilge, 2009). Due to the diversity of the uses of intersectionality, I will clarify my analytical strategy.

\section{Contextual and Relational Intersectionality}

Closely tied to the minority political movements of the 1970s, and in particular to American Black Feminism, the notion of intersectionality emerged first in the United States as an umbrella concept for the strategic and identity dilemmas encountered in the North-American legal and political space by cate- 
gories of people subjected to combined forms of domination. Subsequently, an incipient body of empirical studies on minorities started to take up the challenge of giving an account of how a complex power system structuring particular situations of oppression would generate multiple jeopardy at the intersection of different axes of inequality (Hooks, 1984). In social theory, intersectionality arises then in opposition to oversimplified conceptualizations of the axes of social structure as discrete, in which relationships between race/ethnicity, gender and class are thought of as separate and opposite comparisons, and described by relying on mathematical metaphors such as the multiplication or add-on effect of the burdens of disadvantage (Anthias and Yuval-Davis, 1983; Crenshaw, 1989).

The analytical framework adopted here follows West and Fenstermaker's (1995) proposal to conceive differences and dominance in social life as an ongoing interactional accomplishment that can be elucidated by applying an analysis of the situated, context-based dynamics of the production of inequality and discrimination. By staying anchored to the historical, political and social context from which empirical material is drawn, this case-study examines how context affects the expressions of privilege/oppression and the capability of individuals and social groups to respond to such expressions. It seeks to depict the interweaving of the different axes of social structure that shaped "Roma" migrants access to, and use of the different services, facilities and assets provided through the Sénart Project.

With reference to McCall's typology (2005), the intersectional perspective applied corresponds to the inter-categorical approach. Such an approach develops a relational and process-based reading that at first strategically adopts existing categories to investigate the multidimensional organization of power/ privilege. Struggles and conflicts, rather than groups, are its preferred focus of study (Choo and Ferree, 2010). It conceives that social categories are the result of intertwined processes, the interaction of which produce dynamic and complex patterns of inequality for everyone, not merely the most disadvantaged (Hancock, 2007). It emphasizes sites at which (dis)advantages interplay, coincide or conflict within and between groups and how individuals contend with institutionalized practices and cultural discourses (Bürkner, 2011).

Intersectionality has also been used as a precautionary epistemological tool against the dangers of theorization on the basis of difference (Guillaumin, 1992). Thus, we had to be vigilant with our analytical inferences in order not to fall into the cultural essentialism trap and reify an already historically contested and sociologically problematic, racial-based constructed category, i.e. the so-called "Roma".

Contextual and relational intersectionality is a valuable hermeneutical instrument to critically understand the integration trajectories and identity constructions of "Roma" migrants. Because its analytical framework addresses simultaneously the structuration of social relationships of privilege/oppression and the politics of identity, it supports a conceptualisation of the "Roma issue" as a dual political identity artefact. On one hand, it allows us to explore the fabrication as an ethnic-instrumented class, namely those "small numbers" (Appadurai, 2007) seen as a threat to the safety and the security of living together in an urban setting and discordant with the republican citizenship ideal. Ethnicity is then poli- 
tically exploited for the regulation of foreign, urban margins. On the other hand, it simultaneously brings in the differentiated mechanisms of compensation. This involves in particular institutional contexts of recognition (Honneth, 2005). It conceives minorities as a social force potentially able to invert sets of properties which are originally a handicap into political capital in the public space.

\section{One Affirmative Action Program, Distinct Trajectories of Integration}

The migrants who took part into the Project come from a village of the judet of Timiş (Romania). Their migration trajectory started with the loss of their State employment after the fall of Ceaucescu's dictatorship in 1989 and the economic recession that shadowed the transition from the State-planned, centralized economic system to the liberalization of the economy and the setting up of a free market system. Before 1989, the male members of these families used to work either in the agricultural industry or in refuse collection; the women were mostly employed as collectors of agricultural crops. All of them had eight years of elementary schooling. The pioneers of the emigration were a small number of male breadwinners who, in 1990, went first to Germany. Once there, they could find consecutive temporary jobs in the agricultural industry while awaiting instruction proceedings concerning their demand for asylum. After having their applications turned down, some went back home, and the others tried unsuccessfully to find job opportunities in Belgium. In winter 1991, the latter arrived in the Parisian region where they had heard there were jobs available. After settling in a shantytown in Nanterre, most of the pioneers that had returned home joined them, accompanied now by their spouses and children.

After the shantytown eviction in 1994, they found in the margins of the Sénartaise urban environment a new anchor-point in which to create a place to live. In terms of location this middle-class residential neighbourhood was much valued as it is traversed by the RER D, which connects Sénart to the city of Paris. It offered them a less populous environment, which was perceived as being an easy place to find landmarks but less protective with regard to the prefectural orders of evictions. Reluctant to adopt the nomadic life they were forced to lead, they had opted to restrict their mobility to a perimeter of fifty kilometres, setting up home alongside the RER D, as for lots of them their economic activities took place in the capital. Over time, most individuals built up ties with some Sénartais not only through their begging or flower-selling activities at local markets, but also because some had found short-term regular jobs and succeeded at schooling their children. Moreover, for most of them, the emergency and maternity units of both the Intermunicipal Hospital Center of Villeneuve-Saint-Georges and the Hospital Center of Melun had become their healthcare reference points.

As the family census of the first phase of the Sénart Projet reported, they were socio-economically deprived migrants, little-schooled (the ones born in France being illiterate), having diverse religious affiliations (Pentecostals and Orthodox Christians) and varying family unit configurations (extended, nuclear, mono-parental and single male). They were openly expressing a will to stabilise their livelihood by taking permanent manual jobs, schooling their children and moving to concrete housing, as they had been used to in Romania. 
During the second phase of the Sénart Project, the access to le droit commun system, including those services created by the guidance law of July $29^{\text {th }}, 1998$, relative to the struggle against social exclusion, quickly turned out to be very complicated. Beside the administrative irregularity of most of them - a real obstacle to get regular jobs and to apply for social housing - the embassy of Romania refused to deliver a passport to people who had asked for asylum after 1989. The alliance between State and local authorities made possible a special dispensation in the immigration law allowing the delivery of temporary residence certificates without having to present a job commitment. Without it, the continuation of the Project was straightaway doomed to failure.

Furthermore, the context of social housing shortage and lack of unqualified jobs in the expanding economic local fabric of Sénart put these families in competition with other Sénartais living in deprived conditions. It required all the skills of mediation of the socio-educational team to neutralize the stigma facing the "Roma" families in terms of dealing with public administration, the management agencies of social housing and private employers.

In 2004, when the Second Agreement expired, the delay taken in providing access to social housing prompted criticism from both the Prefecture and the families. The socio-educational team was split between its mission of public service and its professional ethics towards the families. This was happening in the background of the implementation in France of more fiercely repressive immigration policies and the increase in generalized suspicion against migrants. Concerning the Prefectural social housing, they were even situations in which the team had strategically removed the application of a family to avoid the Project being held up as an example of unfair preferential treatment against poor French families. Thus, in three years, only one demand for social housing had succeeded and a second had been accepted and was in the course of execution. Nevertheless at that time, thirty-seven men were employed: sixteen with permanent contracts, nineteen under an "emploi solidarité" contract and two with fixed-term contracts. In a context of rapidly growing and dynamic local economic fabric, the team of social workers focused on access to employment by mobilizing local institutions, in particular the Department of Economic Development of the Sénart Newtown Association, the Centre of Employment and Training and, in lesser measure, the employment agency and the local missions. Alongside this, enhanced but temporary rehousing had been provided for the participants at the newly built travellers' site. The order to move on to this new area increased the impression to the families that they were being taken for a ride.

In this climate of general frustration, a last agreement was signed to extend the Project for thirty months. The partnership with the Prefecture and social housing deciders was strengthened to limit the refusal of the families' applications because of racial prejudices while bringing optimal guarantees for tenants. Finally, in April 2007, twenty-eight of the thirty-four families had finally obtained social housing on the site managed by the Newtown of Sénart and the Prefecture. Families did not benefit from any dispensation; their applications not only met the administrative requirements but were the most compelling. In terms of their employment status, twenty-five people had a permanent contract (fifteen men, ten women), three received unemployment benefit and three had 
sheltered jobs for people with disabilities. In addition, three people received the disabled persons allowance and two others received the Old Age Solidarity Fund. To favour the employment of the more unskilled and deprived adults, the socio-educational team mobilized their personal connections at the town halls and contact directly private employers of the industrial cleaning sector and hypermarkets.

In applying an intersectional perspective to the different integration trajectories, our findings distinguish three main "ideal types" (Weber, 1949) of social and economic development profiles. As shown next, the interlocking of gender, mother's education level, intra-generational power-relations within the household, and health status enacted as constitutive factors for the distinct "routes" of the families. We also examine the differences in the families' lifecourses brought about by the movement of the axes of social structuration. Also, how their positioning in terms of these intersected categories made subjective experiences of the Project qualitatively different.

\section{Families whose Present Remains Entangled with Slum Life}

To begin with, the first ideal type encompasses those families whose social identity and life-course remains deeply tangled with the burdensome background of a decade of slum life. For those adults born within, or knowing since their early age, the shantytown way of life such extreme life experience has prevented them from fully profiting, for the duration of the Project, from the vocational training and employment services put at their disposal to help them attain economic autonomy.

The model of household of the eight families that would fit in this first profile corresponds to the extended family; three generations living together in the same social housing. The second generation of adults is generally illiterate due to the nomadic life they were impelled to carry on in France. They were also too old to be schooled during the Project. They had great difficulties to endorse the discipline required in the vocational training schemes they enrolled in, mainly because they were trapped by their present daily basic needs. They could hardly believe that taking time to invest in training would actually get them out of their extreme situation of poverty.

Their current livelihood mainly depends on disability allowance and social security aid received by the first generation and the income of the elder son normally under a fixed-term contract. In periods of unemployment, they resort to makeshift means or catch-as-catch-can tactics (i.e., begging in railway stations, sale of recycling material or flowers, jobbing in second-hand cars, domestic appliances transaction), by mobilizing their relational capital. This is supplemented with the earnings coming from sporadic hours of house-cleaning made by the adult women of the household.

Another particularity is that care labour and household tasks are entirely taken by the daughters-in-law, who are indeed the only ones who do not speak French. During the Project, first generation family members were reluctant to allow these women to enrol on to the women-specific vocational paths. "But otherwise, who would have taken care of me?" is how one first-generation women with severe health problems replied to me. She continued: 
"Listen, they did not find a house for my son. But we are ok with that, we manage quite well living all together. Now, we are applying for a service-dependency allowance for my husband. I breathe thanks to oxygen therapy; I can hardly walk. Who would take care of me if it was not my daughter-in-law?

My husband does not know much about housework, cooking... My daughter lives in another town; she has too many worries with work and her children"

(Woman, b. 1974 in Romania, France since 1992, married, eight-years schooling in Romania, two children, receiving the disabled persons allowance since 2006).

These comments unravel the intra-familiar unequal power relationships that subject the daughter-in-law into a position of servility. Accordingly, the daughterin-law's social position relates to the daughter's position with an inverse mirror effect. Moreover, following the family-in-law's patterns of thinking, they seem illegitimated to receive a dependency allowance. In addition to the unpaid, taken-for-granted care labour they undertake, these women also play a major role in the schooling of the children by ensuring their regular attendance and the proper care of their school supplies.

The social network of these families was and still remains intra-communitarian, tending to adopt a community risk sharing behaviour. Recurrently, in our different encounters, the first generation members mentioned their dream of coming back to their lost Romania. They are nostalgic of the Romania under Ceaucescu's dictatorship for what they describe as its "protective" governance towards them, the "Tşigans", "who, like everybody, were also assigned with a job and a house". A "hard life", they would commonly agree, "is still better in France than in current Romania". Thoughts concerning ideal projections on the future have hardly been expressed by the second generations, even when I tried to illicit this through direct enquiry. They seem to feel drawn into the present of their very demanding daily life, which they only conceive in France. Thus, France for them is above all their living-place in which they paradoxically feel strangers. I could not get any direct impression from the daughters-in-law on their sense of belonging, their dreams. They were unreachable when busy with care labour tasks at their home. On other occasions, for instance when I would walk with them to school, they were attentively absorbed in the present situations we shared. There, our conversation focused on issues about which they felt comfortable to disclose to me: events concerning the children at school that had made them proud, or worries as regards their children's health.

A differing "route" of integration is represented by those who have embraced the livelihood model of the suburban working class. The families concerned have in common the tendency to look with disdain upon the lifestyle of those who are positioned lower in social space. The "vulgarity" they attach to the "other families" is constructed with despised traits as receiving "too much" from the welfare state, being engaged in unlawful activities and not taking proper care of their children (not respecting the school schedule or allowing them to leave school before they are sixteen).

\section{New Suburban Manual Working-Class Families}

This second ideal type includes eleven couples, in their late-thirties, with children, the elder of which is at least eighteen. In 2010, four families had 
acceded to a private property in France and another one had moved into newer and bigger social housing. All the fathers had a long-term employment contract. They had a past employment experience in Romania in the industry sector, and most in Germany and Belgium too. The mothers had completed schooling up to secondary school level in Romania and had enrolled on to French courses for adults during the Project. Except for two, the women are currently employed in part-time cleaning jobs in public schools and office buildings, after taking part in the women-specific vocational training track (launched in 2003 for over thirty months). This training included French lessons, general information on the labour market, job-hunting and basic professional skills (punctuality, hygiene, codes of interpersonal communication). It also taught them about householdbudget management, nutritional matters, the benefits of times of rest, and contraceptive methods. Their attendance was strictly controlled and if they had children under school-age it compelled them to hire a baby-sitter.

Whilst these women appreciated the French courses and the facilities given to find jobs in public institutions, they were critical towards the contents intended to supposedly fill a void in their competences as housekeepers and mothers. In 2004, some overtly refused keeping doing those things required by the Project that they found absurd, such as taking on a baby-sitter when having a relative for looking after their kids. Recalcitrant acts ensued from the deception felt as regards the Project outcomes:

"What's the use of hiring a nanny when I pay her more than what I receive and there is my father to take care of my children? We did all they asked us, how they asked us to do it. We achieved everything they wanted: my husband got a permanent contract; I had

a full-time fixed-term contract, our children did not skip a day at school, we respected appointments... and by that time, we still did not have a house! You see, Kati! We were so fed up!" (Woman, b. 1976 in Romania, France since 1991, married, eight-years schooled in Romania, three children, successive part-time fixed-term contracts since 2003 in public cleaning sector).

Another sensitive issue often mentioned by these women concerned the proposal that they should get a driving license. Contrary to the social workers' view, a driving license was not seen as an opportunity for emancipation but rather as an additional domestic burden:

"The last year, they insisted on the driving lessons... I thought a lot about it... But in the end, can you imagine it? I would have had to also do the shopping, there, alone or with the children... and, I would have felt compelled to drive them to school, each morning, each evening. No, no, I refused; it would have been more work, and God knows I already do enough" (Woman, b. 1979 in Romania, France since 1992, married, eight-years schooled in Romania, two children, successive part-time fixed-term contracts since 2004 in domestic cleaning).

Parents typically hold high expectations for upward social mobility through their children's schooling. One of the main assets they highlight when they refer positively to the Project is the help received to facilitate children's schooling thanks to the involvement of local authorities and the Project social educator who played a mediation role with the school staff. They appreciated the daily homework support offered by volunteers in the temporary settlement. Once at 
their proper housing, they have kept the routine of checking the homework. Most have also registered their kids into the homework support courses delivered at school. Some parents have motivated their children to do an extracurricular physical activity (basket, judo and break-dance) to become better integrated into school life. A common expectation for their offspring is to get a vocational training qualification.

These families are all practicing Orthodox Christians. They usually come together, two Sundays per month, to celebrate a private religious ceremony taking place each time in a different home, but always conducted by the same "religious authority", namely a participant of the Project who owns a copy of the Bible and is highly respected for his moral values.

Finally, with the strengthening of their sense of belonging to Sénart, an incipient transnational identity emerged. This is expressed in personal initiatives of "helping" their village of origin such as the donation of clothes and food collected in France and delivered in situ in their summertime holidays. Despite their better economic situation, savings invested to finance own real estate projects in Romania, which is a frequent objective for most migrants, were exceptional. For those who were already owners in Romania, a residual budget was allocated for the property maintenance; less often for upgrading it with modern conveniences.

Finally, these families have diversified their social network through their contact at work and school. Even if this is highlighted as a marker of social distinction and of their success in their integration, it is not exempt of concerns as it is also seen as a potential questioning of traditional family cultural values and practices. The parents' impressions on the fact that a French young man was courting their elder daughter offer an illustration of the cultural challenges that diversified relationships entail.

"Father: Come back also next Sunday, you'll meet with the boy who is courting my daughter. He is French [laughs], you know? A friend of the daughter of my boss. They met at a birthday party. Mother [laughing]: umm, the boy seems very nice, very polite but

[Father] is not very happy.

Kàtia: Oh! How can it be possible?

F: Well, you know, it is like your parents...

$\mathrm{K}:$ Umm, what do you mean?

F: Now you are living separately, they are in Spain, you are here with your husband.

$\mathrm{K}:$ Oh I see... We still are very close, frequently in touch. I often visit them.

M: Yes but you don't get it: Spain is not like our village... You've seen it, there are not pavements and ... well, for us it is important to conserve our traditional Sunday meals, here.

F: What if the boy doesn't like our village, or if he gets bored by a day like today, with the ceremony? We will kind of lose her... No longer summer holidays together... It makes me sad, this loss of...

$\mathrm{K}$ : The loss, the weakening of family bonds...

F: Yes, Kati, the French are not like us; family bonds, family traditions and so on" (Reconstituted conversational interview, fieldwork journal). 
The third ideal type concerns the youngest couples formed during the Project, who accessed a social apartment in 2007. These families are deeply disappointed by the promises for social emancipation emanating from the social accompaniment scheme. As developed in next paragraphs, they share the experience of an ethnically-divided labour market, whose discriminative barriers are hard to overcome with merely individual will-power and initiative.

\section{"Broken Expanded-Dreams" Generation}

This ideal type is represented by six couples, in their twenties, with young kids, the elder going to preschool. These nuclear families consist of a father who is generally illiterate and a mother who enrolled on to an adapted secondary school programme as part of the Project.

In these families, the prevailing patriarchal model of domestic task and family care distribution is vindicated by the women. Most have achieved vocational training as hairdressers or shopping assistant. Despite their qualification, they could not get the corresponding job positions. The job opportunities that the French labour market offers them are in the cleaning sector. This disappointing experience has led them to exclusively invest in their domestic life. They hold a very critical view of how to apply the messages that the Project staff overtly and recurrently put forward in favour of the equality between men and women. This is illustrated in the following comments of a participant who was not admitted into the woman-specific vocational training during her pregnancy:

"They advised me to have an abortion because it was better for my professional future. At school, compared to the others, I was already a woman! And I was not going anywhere in terms of results ... Years and years living in slums, we are no longer able to learn how to read and write, there, at school [...]l wanted to keep my daughter. So I could not get onto the training program for women, but [...] afterwards what was the point of getting a hairdresser qualification? Look what happened to her, now with the diploma she can't find a job! [Laughing] She looks too much like a gypsy!" (Woman, b. 1988 in

Romania, France since 1992, two children, begging activity and sporadic paid-hours without contract for domestic cleaning).

For the men, as they had never been schooled before the Project, they were registered in literacy courses before engaging in vocational training of the Local Mission addressed to young people whose learning disabilities are the result of accumulative social deprivation. Most are now earning a livelihood with successive part-time contracts as cleaning staff, on construction sites, or as store assistants in supermarket warehouses. For the two who were receiving social security benefits when we met, they had severe difficulties maintaining their last job position with a public gardening enterprise. According to them, they resigned because of their difficulties respecting the requested work schedule and conflictive relationships with the other employees, also under subsidized contracts. 


\section{Conclusion}

As with most actions targeting Roma populations in Europe, the Sénart Project envisaged its beneficiaries as both victims (of violence and discrimination) and offenders (antisocial behavior, irregularity, and crime). Its study brings to the fore the controversies inherent in managing specifics based on ethnicity: Are differences to be protected or should peculiarities be bent for the sake of integration (Ragaru, 2015)? It displays also the intricacies between the protective and security aspects concerning the issue of the integration of minorities (Lurbe i Puerto, 2015). Although unique in its kind in France, this affirmative action remained anchored in a prevailing positioning notion in favor of cultural assimilation and a National security-based approach to the issue.

The Sénart Project set up owed itself to the partnership it involved between the State, local authorities and a wide range of community health, education, economic and social players. Its privileged relationship with the Prefecture allowed a series of dispensations regarding the Migration Law in order to break the work and residence permits circle, which is a major obstacle to the integration of migrants. The resources allocated during its last five years to provide a specific socio-educational accompaniment helped compensate part of the backwardness of years of living in slums. The ethnographical data on the families' trajectories completes the picture by introducing a necessary condition for its success: the resourcefulness of the migrants themselves (Legros and Olivera, 2014). The stability brought by the Project helped consolidate their already existing links with the local society and mobilize efficiently their relational capital.

The Project is described by the families who had access to a resident permit and social housing as a turning point in their life-course. But, getting on the route to become a full city-dweller turned out to be very demanding for them because of lack of housing opportunities and regular, sufficiently-paid jobs for illiterate workers, and because of institutional racism underpinning the employment and housing market place. The outcomes reached by the whole families put into question not only the widely taken-for-granted lack of initiative and willpower for social integration of the "Roma". Indeed, they show how residential situations determine the modes of economic and social insertion and vice versa. It also brings into play arguments for the need to implement affirmative action so that migrant populations with irregular administrative status can enter into common law. Different and differing pathways of integration have been traced not only due to the singular trajectory and particular social positioning of each individual, but also as a result of the social values highlighted by the Project through the type of group-specific actions undertaken.

Subsequently, the shortage of housing and the presence of severe health problems among the grandparent generation have tended to reinforce the unequal inter-generational power relationship among those family units that accumulate big social disadvantages. Within deprived extended-type households, a category of woman is much oppressed: the daughter-in-law. Also within such family settings, the recognition of a disability marked with a social security allowance has upgraded the positioning of the senior women. In the case in which the husband of these women is unemployed, this recognition has even led them to overtake the breadwinner role. 
Time is a key vector in affirmative action with fixed deadlines. Adults with higher educational levels have benefitted more from the set of services put at their disposal. But this assertion should be slightly nuanced as this privileged educational level can be counteracted by age positioning. This is the case for the youngsters who, due to their age, came late to benefit from accompaniment offered by the Project for job-seeking. One of the missions of its staff implied the development of actions addressed to potentials employers: of breaking stereotypes and raising awareness of the labour-value of "Roma" candidates. Finally, a past experience in the French marketplace for the men in their late twenties and thirties, along with the fact of having stable family relationships with a spouse with secondary school level schooling in Romania, have indeed advantaged some families.

Finally, for the families, although they recognize its value in terms of the different resources acquired, the experience was testing. On one hand, they had to persevere in the face of the shortage of social housing and a very penalizing labour market for people with little or lacking in qualifications. On the other hand, the rigidity and slowness of administrative procedures, as well as the fixation on a deadline which was independent to the completion of the Project's objectives, are strongly perceived as disdainful towards their constant efforts and to them as human beings. This wound remain anchored in their memory and is a reminder of their past slum lives.

\section{References}

Anthias Floya and Yuval-Davis Nira (1983) Contextualizing Feminism: Gender, Ethnic and Class Divisions, Feminist Review, 15, pp. 62-75.

Appadurai Arjun (2007) Géographie de la colère. La violence à l'âge de la globalisation, Paris, Payot, 207 p.

Asséo Henriette (2004) Les Gypsy Studies et le droit européen des minorités, Revue d'histoire moderne et contemporaine, 5 (51-4bis), pp. 71-86.

Asséo Henriette (1994) Les Tsiganes, une destinée européenne, Paris, Gallimard, $160 \mathrm{p}$.

Bessone Magali, Doytcheva Milena, Duez Jean Baptiste, Girard Charles and Guérard de la Tour Sophie (2013) Integrating or Segregating Roma Migrants in France in the Name of Respect: A Spatial Analysis of the Villages d'insertion, Journal of urban Affairs, (36) 2, pp. 182-196.

Bilge Sirma (2009) Théorisations féministes de I'intersectionnalité, Diogène, 225, pp. 70-88.

Bürkner Hans Joachim (2011) Intersectionality: How Gender Studies Might Inspire the Analysis of Social Inequality among Migrants, Population, Space and Place, (18) 2, pp. 181-195.

Canut Cécile et Hobé Alain (2011) Roms et compagnie, Ligne, 34, pp. 7-23.

Choo Hae Yeon and Ferree Myra Marx (2010) Practicing intersectionality in sociological research: A critical analysis of inclusions, interactions and institutions in the study of inequalities, Sociological Theory, 28, pp. 147-167. 
Christensen Ann-Dorte and Jensen Sune Qvotrup (2012) Doing intersectional Analysis: Methodological implications for Qualitative Research, Nordic Journal of Feminist and Gender Research, (20) 2, pp. 109-125.

Cossée Claire (2010) L'impossible neutralité des sciences sociales face aux catégorisations militantes "Tsiganes ", Gens du voyage, Rroms aux autres ethnonymes ?, Migrations Société, 22 (128), pp. 1-18.

Crenshaw Kimberlé Williams (1989) Demarginalizing the Intersection of Race and Sex: A Black Feminist Critique of Antidiscrimination Doctrine, Feminist Theory and Antiracist Politics, University of Chicago Legal Forum, 140, pp. 138-167.

Doytcheva Milena (2015) Roms etTsiganes en Europe Méditerranéenne : I'actualité d'une question, Confluences Méditerranéennes, 93, pp. 9-25.

Doytcheva Milena (2007) Une discrimination positive à la française ?, Paris, La Découverte, 226 p.

Fassin Éric (2014) La "question rom ", in Éric Fassin, Carine Fouteau, Serge Guichard et Aurélie Windels, Roms \& Riverains. Une politique de la race, Paris, La Fabrique, pp. 7-70.

Fouteau Carine (2014) Hors du commun, hors des communes. De Ris-Orangis à Grigny, un an dans la vie d'un bidonville, in Éric Fassin, Carine Fouteau, Serge Guichard et Aurélie Windels, Roms \& Riverains. Une politique de la race, Paris, La Fabrique, pp. 71-108.

Geisser Vincent (2005) Ethnicité Républicaine versus République ethnique ?, Mouvements, (38) 2, pp. 19-25.

Guillaumin Colette (1992) Sexe, Race et Pratique du pouvoir. L'idée de Nature, Paris, Côté-femmes, 239 p.

Hancock Ange-Marie (2007) When Multiplication doesn't Equal Quick Addition: Examining Intersectionality as a Research Paradigm. Perspectives on Politics, 5, pp. 63-79.

Honneth Axel (2005 [1995]) The Struggle for Recognition, Cambridge, Polity Press, $215 \mathrm{p}$.

Hooks Bell (1984) Feminist theory: From margin to center, Boston, South End Press, $179 \mathrm{p}$.

Legros Olivier (2014) La gauche au pouvoir et les Roms en France : réflexions sur une politique en cours de construction, in Marc Bernardot, Arnaud Le Marchand, Catalina Santana Bucio Dirs., Habitats non ordinaires. Les espace-temps de la mobilité, Paris, Éditions du Croquant, 364 p.

Legros Olivier (2010) Les "villages d'insertion " : un tournant dans les politiques en direction des migrants roms en région parisienne ?, Asylon(s), 8 [en ligne] consulté le 19/11/2015. URL : http://www.reseau-terra.eu/article947.html

Legros Olivier et Olivera Martin (2014) La gouvernance métropolitaine à l'épreuve de la mobilité contrainte des "Roms migrants " en région parisienne, [en ligne] consulté le 19/11/2015. URL : http://www.espacestemps.net/articles/ Imobilite-contrainte-des-roms-migrants-en-region-parisienne/

Legros Olivier and Vitale Tommaso (2011) Les migrants roms dans les villes françaises et italiennes : mobilités, régulations et marginalités, Géocarrefour, (86) 1, pp. 3-14. 
Liégeois Jean-Pierre (2012) The Council of Europe and Roma - 40 years of action, CoE Publishing, $207 \mathrm{p}$.

Lussault Michel (2009) De la lutte des classes à la lutte des places, Paris, Grasset, 220 p.

Lurbe i Puerto Kàtia (2015)The insertion of Roma in Sénart Project (2000-2007): A local minority-targeted affirmative action following in the footsteps of the French republican citizenship model, Identities: Global Studies in Culture and Power, $22(6)$, pp. 653-670.

Lurbe i Puerto Kàtia (2013) Sénart : une victoire à I'arraché, Plein droit, (4) 99, pp. 13-16.

Lurbe i Puerto Kàtia et Le Marcis Frédéric (2012) Exclusion, reconnaissance et expériences des " endoétrangers " en Europe, in Kàtia Lurbe i Puerto et Frédéric Le Marcis Éds., Exclusion, reconnaissance et expériences des "endoétrangers " en Europe. Rroms, Manouches, Gitans et " gens du voyage ", Bruxelles, Academia-Bruylant, pp. 7-32.

Maillary Caroline (2013) Diagnostiquer pour mieux trier, Plein droit, (4) 99, pp. 11-12.

McCall Leslie (2005) The complexity of intersectionality, Signs: Journal of Women in Culture and Society, 30, pp. 1771-1802.

Olivera Martin (2013) Insertion ou bricolage ?, Plein droit, (4) 99, pp. 7-10.

Olivera Martin (2011) La fabrique experte de la " question rom " : multiculturalisme et néolibéralisme imbriqués, Ligne, 34, pp. 104-118.

Ragaru Nadège (2015) Les productions internationales et locales des frontières ethnoculturelles : les Roms de Bulgarie saisis par les institutions, Confluences Méditerranéennes, 93, pp. 27-37.

Reyniers Alain (1993) Les Tsiganes en Roumanie : situation socio-économique et identité, Études Tsiganes, 39 (2), pp. 60-73.

Robert Christophe (2007) Éternels étrangers de l'intérieur, Paris, Desclée de Brouwer, $452 \mathrm{p}$.

Simon Patrick et Zappi Sylvia (2005) La politique républicaine de I'identité, Mouvements, 38, pp. 5-7.

Stewart Michael (2002) Underclass, Race and "the Roma" in Post-communist eastern Europe, in Chris Hann Ed., Postsocialism: Ideas, Ideologies and Practices in Europe and Asia, London, Routledge, pp. 133-155.

Weber Max (1949) The methodology of the social sciences, New York, The Free Press of Glencoe, $188 \mathrm{p}$.

West Candace and Fenstermaker Sarah (1995) Doing Difference, Gender and Society, (9) 1, pp. 8-37.

Windels Aurélie (2014) "Riverains " et autres "voisins ", in Éric Fassin, Carine Fouteau, Serge Guichard et Aurélie Windels, Roms \& Riverains. Une politique de la race, Paris, La Fabrique, pp. 109-153. 


\title{
Kàtia Lurbe i Puerto
}

\section{... From Slum to City Dweller, Trajectories of Integration of the "Roma" Families of an Affirmative Action Program in France}

\begin{abstract}
"Roma" populations in Europe and their relationships with the Nation-State have for long been a sensitive political issue. By focusing on the "Roma sequence of 2010", this article addresses first the political fabrication of the "Roma issue" in France. It then applies an intersectional analysis to the trajectories of social integration of the families of the Sénart Project (2000-2007). The empirical material is drawn from the documentary analysis of the Project archives and four years of ethnographical work. Three major questions are explored: What assessment do the families make of the Project? What ideal types of integration trajectory can be inferred from the case-study? What characterises each of them?

\section{Du bidonville à la vie citadine, les trajectoires d'intégration de familles "roms " ayant participé à un projet de discrimination positive en France}

La présence de populations "roms " en Europe et leurs relations avec l'ÉtatNation représente, depuis longtemps, une question politique sensible. En se basant sur "la séquence rom de 2010 ", cet article examine la fabrication politique de la question " rom " en France. II applique ensuite I'approche intersectionnelle à l'étude des trajectoires d'intégration des familles "roms " du Projet de Sénart (2000-2007). Le matériau empirique comprend une analyse d'archives et l'enquête ethnographique de quatre ans auprès des familles. Trois interrogations guident nos réflexions : quel bilan font les familles du Projet? Quels types idéaux de trajectoires d'intégration ressortent de l'étude de cas ? En quoi se caractérisent-ils ?

\section{Del chabolismo a la vida citadina, las trayectorias de integración de familias uroma" que participaron a un proyecto de acción positiva en Francia}

La presencia de poblaciones "roma» en Europa y sus relaciones con el Estadonación constituyen una cuestión política sensible. Partiendo de "la secuencia roma de 2010", este artículo examina primero la fabricación política de la "cuestión roma» en Francia. A continuación, aplica un análisis interseccional al estudio de las trayectorias de integración de las familias del Proyecto de Sénart (2000-2007). Este estudio se basa en el análisis documental de los archivos del Proyecto y un trabajo etnográfico de cuatros años. Tres preguntas articulan nuestras reflexiones: ¿Qué balance hacen las familias sobre el Proyecto? ¿Qué tipos ideales de trayectorias de integración se infieren del estudio de caso? ¿Qué los caracteriza? 